\title{
Potential of corncobs (Zea mays) fraction as tyrosinase inhibitor and natural antioxidant in vitro
}

\author{
${ }^{1,2}$ Dewi, I.K., ${ }^{2, *}$ Pramono, S., ${ }^{3}$ Rohman, A. and ${ }^{4}$ Martien, R. \\ ${ }^{1}$ Department of Indonesian Traditional Herbals, Poltekkes Kemenkes Surakarta, Central Java 57425 \\ Indonesia \\ ${ }^{2}$ Department of Biology Pharmacy, Faculty of Pharmacy, Universitas Gadjah Mada, Yogyakarta, Indonesia \\ ${ }^{3}$ Institute of Halal Industry and Systems, Universitas Gadjah Mada, Yogyakarta 55281 Indonesia \\ ${ }^{4}$ Department of Technology Pharmacy, Faculty of Pharmacy, Universitas Gadjah Mada, Yogyakarta,
}

Indonesia

\begin{abstract}
Article history:
Received: 24 August 2020

Received in revised form: 12 October 2020

Accepted: 15 October 2020

Available Online: 27

February 2021

Keywords:

Corncob,

Tyrosinase,

Antioxidant,

$\mathrm{DPPH}$,

Total phenolic,

Total flavonoids

DOI:

https://doi.org/10.26656/fr.2017.5(2).465
\end{abstract}

\begin{abstract}
Corncobs (Zea mays) are beneficial to human health as they contain tyrosinase inhibitors and natural antioxidants, but they are not used as they are considered as waste. This research evaluated the inhibition test towards tyrosinase enzyme and antioxidant activity of corncob fraction using in-vitro DPPH method and its correlation to phenolic and flavonoids. Corncob fraction was extracted using the maceration method applying $70 \%$ ethanol solvent. The ethanol extract of corncob was suspended by water and then partitioned with chloroform, ethyl acetate, and aquadest to produce three fractions (chloroform, ethyl acetate, and aquadest fractions). These fractions were analyzed through the tyrosinase inhibition test, applying in vitro tyrosinase enzyme inhibition and antioxidant activity using radical scavenging test DPPH (2 2,2-diphenyl-1-picrylhydrazyl). Meanwhile, the total phenolic and flavonoids content tests were determined spectroscopically. The results showed ethyl acetate fraction had the highest tyrosinase activity with $\mathrm{IC}_{50}$ values of $185.76 \mu \mathrm{g} / \mathrm{mL}$, followed by the aquadest fraction $\left(\mathrm{IC}_{50}\right.$ $676.44 \mu \mathrm{g} / \mathrm{ml}$ ) and the chloroform fraction $\left(\mathrm{IC}_{50} 709.26 \mu \mathrm{g} / \mathrm{mL}\right)$. The antioxidant activity using DPPH radical scavenging method exhibited that ethyl acetate fraction had the highest antioxidant activity with $\mathrm{IC}_{50}$ of $25.79 \mu \mathrm{g} / \mathrm{mL}$ followed by the chloroform fraction ( $\mathrm{IC}_{50}$ of $29.15 \mu \mathrm{g} / \mathrm{mL}$ ) and the aquadest fraction $\left(\mathrm{IC}_{50}\right.$ of $\left.32.41 \mu \mathrm{g} / \mathrm{mL}\right)$. The total phenolic content of the corncob fraction ranged between 1.73 to $7.43 \%(\mathrm{w} / \mathrm{w})$ gallic acid equivalents (GAE), while the entire flavonoid content ranged between 0.01 to $1.34 \%(\mathrm{w} /$ $\mathrm{w})$ quercetin equivalent (QE). The tyrosinase activity and antioxidants of the corncob fractions correlated with the total phenolic and flavonoid contents.
\end{abstract}

\section{Introduction}

Indonesia is an agrarian country abundant in the availability of crop resources. Corn is one of the major crops in Indonesia. Based on Badan Pusat Statistik (2019), corn yields in 2015 were 19.612.435 tons and increased by 604,009 thousand tons compared to 2014 . Corn kernel is a food source while the corncob is discarded resulted in a large amount of waste. The data from Direktorat Jenderal Tanaman Pangan, the Ministry of Agriculture (2015) showed about 13 million tons of corncob waste were produced in Indonesia.

Although corncobs are commonly discarded, they do have some health benefits. Dong et al. (2014) found that corncobs contain flavonoids that were proven to correlate with antioxidant. Aside from flavonoids, corncobs are claimed to have other health properties, such as anti-tumor (Melo-Silveira et al., 2019), antifungus (Asadollahi et al., 2012), and antioxidants (Li et al., 2014).

An antioxidant can inhibit reactive oxygen species (ROS) and/or reactive nitrogen species (RNS) as well as free radicals (Halliwell, 2006). An antioxidant can be obtained from natural and synthetic sources (Herlina et al., 2018). The synthetic antioxidants included BHA (Butylated Hydroxy Anisole), BHT (Butylated Hydroxy Toluene), PG (Propyl Gallate), and TBHQ (Tertiary Butyl Hydro Quinone). Synthetic antioxidants are more 
effective, but in the recent studies had proven that some synthetic antioxidants can cause toxic and mutagenic effects (Alnajar et al., 2012). Therefore, it is necessary to perform research on natural antioxidants. The phenolics content in corncob was reported to have good antioxidants in preventing free radicals (Lumempouw et al., 2012; Dong et al., 2014).

Flavonoids compound is reported to have acted as tyrosinase enzyme inhibitor (Jegal et al., 2016). The skin has melanin, which is black pigment that protect human's skin from excessive Sun's ultraviolet exposure, while tyrosinase is an enzyme that plays an essential role in melanin production (Jin et al., 2018). A whitening agent works in the melanin production stage with a mechanism to inhibit tyrosinase enzyme maturation or inhibit granule pigment (melanosomes) from melanocytes to keratinocytes around them. The whitening agent mechanism works by controlling exosome secretion which is secreted from melanocytes (Bin, 2018). Therefore, a phytochemical compound that can inhibit tyrosinase enzyme as melanin producer is needed.

The antioxidant activity of corncob fractions has previously been reported using DPPH radical scavenging method. The result showed that ethyl acetate fraction has the highest DPPH radical scavenging, compared to butanol, ethanol, petroleum ether, and water fractions (Suryanto and Momuat, 2017). The previous study also reported that corncob extracts of ethanol $50 \%$ ethanol extract, $80 \%$ methanol extract, $50 \%$ methanol extract, $80 \%$ methanol, and ethyl acetate extract exhibited antioxidant activities using DPPH, ABTS (acid 2,2Azinobis-3-etilbenzatiazolin-6-sulfonate) and FRAP (Ferric reducing-antioxidant power) methods (Dong et al., 2014). However, corncob fractions (chloroform, ethyl acetate, and water) toward tyrosinase enzyme inhibitor and DPPH assay method and its correlation with total phenolic and flavonoid contents have not been reported yet. Therefore, this research aimed to evaluate the activity of tyrosinase enzyme inhibition and evaluate antioxidant activity using the DPPH method and its correlation to phenolic and flavonoids.

\section{Materials and methods}

\subsection{Materials}

Corncobs were obtained from local farmers in Klaten, Central Java, Indonesia. In addition, this research used 2,2-diphenyl-1-picrylhydrazyl (DPPH, from Sisco Research Laboratories), Kojic Acid (p.a., Tokyo Chemical Industry), Mushroom Tyrosinase (from SigmaAldrich), L-Beta-3,4-dihydroxyphenylalanine (L-DOPA, p.a Sigma-Aldrich), methanol (E. Merck, Darmstadt
Germany), dimethyl sulfoxide (DMSO from SigmaAldrich), quercetin (p.a., Sigma-Aldrich), gallate acid (p.a., Sigma-Aldrich), chloroform (p.a., Merck).

\subsection{Sample preparation}

Corncobs were dried and ground into powder form with a specific advanced degree according to the mesh measurement standard. Extraction was carried out using $100 \mathrm{~g}$ of corncob powder in $1 \mathrm{~L} 70 \%$ ethanol via maceration. The macerated liquid was then evaporated using a rotary evaporator water bath. The concentrated corncob extract was then dissolved in pre-heated water/ aquadest and further separated using chloroform and ethyl acetate to produce three types of fractions: chloroform, ethyl acetate and water (Suryanto et al., 2017).

\subsection{Qualitative identification of flavonoids and antioxidants using thin-layer chromatography (TLC)}

Each corncob fraction was dissolved in $100 \mathrm{mg} / \mathrm{mL}$ of solvent, then $10-20 \mu \mathrm{L}$ was smeared onto the silica gel plate and eluted using a chloroform-methanol solvent with a ratio of 8:2 as the elution phase. After the elution, the silica gel plate was then dried, and the separation was observed under UV 254 and UV 366, and was sprayed with cytoborate reagent and DPPH reagent.

\subsection{Total phenolic determination}

The determination of total flavonoids was performed according to Farmakope Herbal Indonesia (Kemenkes, 2017). Approximately $100 \mathrm{mg}$ of the fraction was weighed into an Erlenmeyer flask and added with $25 \mathrm{~mL}$ of methanol P. The mixture was stirred for an hour with a magnetic stirrer before filtered into a $25 \mathrm{~mL}$ flask. Methanol $\mathrm{P}$ was added until the mark.

For pure compound solution, $10 \mathrm{mg}$ of gallic acid was weighed into $25 \mathrm{~mL}$ flask and added with methanol $P$ until the mark. A series of dilution was performed on the mixture to make different concentration levels of $100,70,50,30,15$, and $5 \mu \mathrm{g} / \mathrm{mL}$. An aliquot of $1 \mathrm{~mL}$ of the test solution was added into each series of the pure compound solution. Approximately $5 \mathrm{~mL}$ of retail FolinCiocalteu LP (7.5\% in water) was added and allowed to stand for 8 mins. After that $4.0 \mathrm{~mL} 1 \% \mathrm{NaOH}$ was added and incubated for $1 \mathrm{hr}$. The absorption of each solution was measured at $730 \mathrm{~nm}$. A calibration curve was produced, and blank was conducted in the same manner without adding test solutions. The total phenolic content was expressed as gram equivalent gallate acid every 100 g subfraction dry weight ( $\% \mathrm{w} / \mathrm{w}$ EAG). 


\subsection{Total flavonoids determination}

Total flavonoid was also determined according to Farmakope Herbal Indonesia (2017). Approximately 50 $\mathrm{mg}$ of the corncob fraction was weighed into an Erlenmeyer flask and added with $25 \mathrm{~mL}$ ethanol P. The mixture was stirred with a magnetic stirrer for $1 \mathrm{hr}$ and then filtered into a $25 \mathrm{~mL}$ flask. The filter paper was rinsed with 70\% LP ethanol. 70\% LP ethanol was added into the $25 \mathrm{~mL}$ flask to top up. Approximately $10 \mathrm{mg}$ of quercetin was weighed into a $25 \mathrm{~mL}$ volumetric flask. Ethanol $\mathrm{P}$ was added to dissolve and further top up to the mark. A series of dilutions was prepared at 100, 75, 50, and $25 \mu \mathrm{g} / \mathrm{mL}$. For each dilution prepared, $0.5 \mathrm{~mL}$ of the test solution, $1.5 \mathrm{~mL}$ ethanol $\mathrm{P}, 0.1 \mathrm{~mL}$ of $10 \%$ aluminum chloride $\mathrm{P}, 0.1 \mathrm{~mL} 1 \mathrm{M}$ sodium acetate and $2.8 \mathrm{~mL}$ was added. The mixture was allowed to stand for 30 mins at room temperature. The absorption of each solution was measured at $730 \mathrm{~nm}$. A calibration curve was produced, and blank was conducted in the same manner without adding test solutions. The total flavonoid content was expressed as gram equivalent quercetin every $100 \mathrm{~g}$ subfraction (\% w/w EK).

\subsection{Antioxidant activity determination}

The antioxidant activity was determined using the DPPH method (Kikuzaki et al., 2002). Each $50 \mu \mathrm{L}$ of corncob fraction with varied concentration was added with $1.0 \mathrm{~mL} 0.4 \mathrm{mM}$ DPPH and $3.950 \mathrm{~mL}$ of ethanol of then mixed in the vortex. After 30 mins, the absorbance was measured at $517 \mathrm{~nm}$ wavelength. The absorbance level was also examined in the blank solutions $(50 \mu \mathrm{L}$ of fraction and $4.950 \mathrm{~mL}$ of ethanol) and the control solution $(1.0 \mathrm{~mL}$ of $0.4 \mathrm{mM} \mathrm{DPPH}$ and $4.0 \mathrm{~mL}$ of ethanol).

The amount of antioxidant activity was counted using the formula:

Percent (\%) antioxidant activity $=\frac{(\text { Abs control }- \text { Abs sample })}{\text { Abs control }} \times 100 \%$

\subsection{In vitro tyrosinase inhibition test}

Exactly $4.96 \mathrm{mg}$ of L-DOPA was dissolved in $10 \mathrm{~mL}$ phosphate-buffered solution $(\mathrm{pH}=6.8)$. The mixture was protected from light (Arung et al., 2005). Approximately $1 \mathrm{mg}$ of tyrosinase was dissolved in $10 \mathrm{~mL}$ phosphatebuffered solution $(\mathrm{pH}=6.8)$ and protected from light. The dissolved tyrosinase had an activity of 496 units $/ \mathrm{mL}$. The solutions were kept at low temperature $\left(2-8^{\circ} \mathrm{C}\right)$ (Arung et al., 2005). To prepare the positive control, exactly $20 \mathrm{mg}$ kojic of acid powder was dissolved in 10 $\mathrm{mL}$ phosphate-buffered solution $(2000 \mu \mathrm{g} / \mathrm{mL})$ and serially diluted to form concentrations of 1500,1000 , $500,250,125$, and $62.5 \mu \mathrm{g} / \mathrm{mL}$ (Batubara et al., 2010).
The corncob fraction was weighed $20 \mathrm{mg}$ and then dissolved in $1 \mathrm{~mL}$ of DMSO. The mixture was added with $10 \mathrm{~mL}$ phosphate-buffered solution $(\mathrm{pH}=6.8)$ and serially diluted to form concentrations of 1500,1000 and $500 \mu \mathrm{g} / \mathrm{mL}$ (Batubara et al., 2010). In four test tubes (A, $\mathrm{B}, \mathrm{C}$ and $\mathrm{D}), 110 \mu \mathrm{L}$ of $2.5 \mathrm{mM}$ L-DOPA solution and 3 $\mathrm{mL}$ of phosphate-buffered solution $(\mathrm{pH}=6.8)$ was transferred. The tubes were incubated for 10 mins. Approximately $0.13 \mathrm{~mL}$ of phosphate-buffered solution and $70 \mu \mathrm{L}$ of tyrosinase enzyme was transferred to Tube A; $0.2 \mathrm{~mL}$ of a phosphate-buffered solution was transferred to Tube B; $0.13 \mathrm{~mL}$ of the sample solution and $70 \mu \mathrm{L}$ tyrosinase enzyme solution was transferred to Tube C; and 0.1 phosphate-buffered solutions and 0.1 sample solution was transferred to Tube D. All tubes were incubated for 25 mins and their absorbance levels were read at $475 \mathrm{~nm}$ wavelength. The inhibition percentage was calculated using the formula as follows:

$$
\% \text { Inhibition }=\frac{(A-B)-(C-D)}{(A-B)} \times 100 \%
$$

Where $\mathrm{A}$ is the absorbance blank solution is negative with enzyme, B is the absorbance blank solution is negative without enzyme, $C$ is the absorbance sample solution with enzyme, and D is the absorbance sample solution without enzyme.

\section{Results and discussion}

\subsection{Qualitative flavonoids and antioxidant contents by} $T L C$

There are different kinds of tests to measure antioxidant activity, but this research prefers to use the DPPH method because it is easier, faster, and more sensitive and uses little amount of sample. Moreover, this DPPH method has been reported as an antioxidant test on corncob (Li et al., 2014). The qualitative test on antioxidant activity can be done by using Thin Layer Chromatography (TLC). The corncob fraction was eluted in silica gel F254 plate and eluted by chloroform: methanol $(8: 2)$ as a mobile phase. The reason behind choosing chloroform: methanol (8:2) mobile phase, which polarity is semipolar, aims to elute all fractions with a different polarity. DPPH was then sprayed the eluted TCL plate. The spotted part has color change into yellow, which shows that there is antioxidant activity (Molyneux, 2004). The antioxidant compound will react with DPPH employing a hydrogen atom donation mechanism to be color shedding, form purple to yellow (Molyneux, 2004).

The eluted corncob fraction spots can be detected at UV 254 ray, UV 366 ray, cytoborate sprayed reagent for flavonoids compound's specific reagent, and DPPH reagent to know the antioxidant profile. Figure 1 shows the results of observations of spots on the corncob 
chloroform fraction almost reaching the elution limit because the chloroform fraction content is a non-polar compound, whereas, in the aqueous fraction, there are spots on the bottling base which show a polar compound so that it does not elute with a semipolar mobile phase. The corncob ethyl acetate fraction has many spots, which in UV 254 offers fluorescence damping. In contrast, UV 366 has faded yellow fluorescence after sprayed with yellow fluorescence cytroborate reagent, so it can be concluded based on the detection results that the positive ethyl acetate fraction contains flavonoids (Kemenkes, 2017). The result of spot observation after it was sprayed with cytoborate showed that the ethyl acetate fraction undergoes colour intensity change at UV $366 \mathrm{~nm}$, from purple (before being sprayed by cytoborate) to yellow (after being sprayed by cytoborate). Cytoborate reagent is a specific reagent with the highest sensitivity to detect flavonoid content and specific for an orto-dihidroxi cluster, so it can be concluded that ethyl acetate fraction is the most dominant fraction which contains flavonoids content.

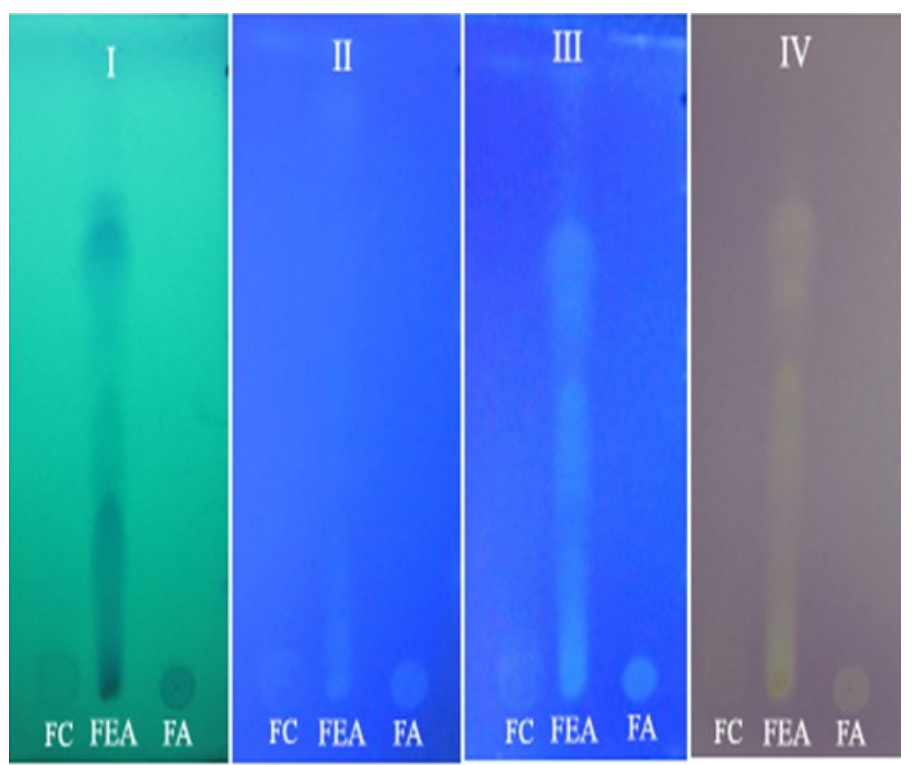

Figure 1. TLC profile with corncob fraction on silica gel F254 plate with chloroform: methanol $(8: 2)$ mobile phase and detected with I. UV254, II. UV366, III. UV 366 after being sprayed with Citroboric reagent and IV. Ray appeared after being sprayed by DPPH. FC: Fraction of Chloroform; FEA: Fraction of Ethyl Acetate, FA: Fraction of Aqueous

The TLC plate's detection result after sprayed by DPPH reagent shows that the most dominant yellow spots are ethyl acetate fraction, which means ethyl acetate fraction is the more potent antioxidant activity of a sample. This has more ability to ward off the DPPH free radicals' compound (Molyneux, 2004), therefore qualitatively concluded that corncob's ethyl acetate fraction has the most dominant antioxidant activity.

\subsection{Total phenolic and flavonoids content}

Based on the previous research, it was proven that the compounds which take responsibility for the antioxidant activity are phenolic and flavonoids, so the antioxidant action from natural ingredients correlated with phenolic and flavonoids compounds (Petrillo et al., 2016; Rohman et al., 2017; Riswahyuli et al., 2019). The result of phenolic and flavonoids content measurement can be seen in Table 1 .

Table 1. Total phenolic and flavonoids content of corncob fraction

\begin{tabular}{lcc}
\hline Fraction & Phenolic $^{\left({ }^{*}\right)}$ content & Flavonoids $^{(* *)}$ content \\
\hline Chloroform & 1.78 & 0.01 \\
Ethyl acetate & 7.43 & 1.34 \\
Aquadest & 1.73 & 0.1 \\
\hline
\end{tabular}

$(*)=\% \mathrm{w} / \mathrm{w} \mathrm{EAG}$

$(* *)=\% \mathrm{w} / \mathrm{w}$ EK

Table 1 shows that ethyl acetate fraction has phenolic content valued $7.43 \% \mathrm{w} / \mathrm{w}$ EAG higher than chloroform fraction and aqueous fraction, whereas for flavonoids result is also reported that ethyl acetate fraction has flavonoids content valued $1.34 \% \mathrm{w} / \mathrm{w}$ EK. It is the highest among the other fractions. This result corresponds with the qualitative antioxidant identification result, which shows that the dominant spot result comes from ethyl acetate fraction.

\subsection{Antioxidant activity determination}

DPPH method was chosen to conduct in vitro on the antioxidant activity of the corncob fraction. The DPPH method principle of measurement is based on the compound's ability to experience DPPH radical color intensity decrease by counting its absorbance level at 517 $\mathrm{nm}$ wavelength (Sehwag and Das, 2014). The parameter to interpret that a compound has antioxidant activity ability is the $\mathrm{IC}_{50}$ value, which means the concentration from a substrate causes $50 \%$ of DPPH activity (Molyneux, 2004). The smaller $\mathrm{IC}_{50}$ value shows that the compound is more active as an antioxidant. The result of the $\mathrm{IC}_{50}$ value antioxidant activity of corncob fraction is shown in Table 2.

Table 2. $\mathrm{IC}_{50}$ value antioxidant activity of corncob fraction

\begin{tabular}{lc}
\hline Fraction & $\mathrm{IC}_{50}$ value $(\mu \mathrm{g} / \mathrm{mL})$ \\
\hline Chloroform & 93.79 \\
Ethyl acetate & 25.79 \\
Aquadest & 32.41 \\
\hline
\end{tabular}

The result in Table 2 shows that the largest antioxidant activity is corncob ethyl acetate fraction with $\mathrm{IC}_{50}$ value parameter $25.79 \mu \mathrm{g} / \mathrm{mL}$, Meanwhile the aqueous and chloroform fractions have bigger $\mathrm{IC}_{50}$ value is $32.41 \mu \mathrm{g} / \mathrm{mL}$ and $93.79 \mu \mathrm{g} / \mathrm{mL}$. Based on this result so it can be concluded that ethyl acetate fraction had antioxidant activity correlation with flavonoids and total 
phenolic content. Flavonoids compound can reduce free radicals' oxidation by donating hydrogen atom so that it can act as antioxidant (Gupta, 2015)

\subsection{Tyrosinase enzyme inhibition}

The purpose of tyrosinase enzyme inhibition testing is to know the corncob fraction's ability to inhibit tyrosinase in forming melanin. The enzyme used in this test is mushroom tyrosinase with substrate L-DOPA and kojic acid as a positive control. It is known that kojic acid is a tyrosinase inhibitor that is clinically used to overcome skin hyperpigmentation (Hashemi and Emami, 2015). The result of corncob fraction tyrosinase enzyme inhibition with $\mathrm{IC}_{50}$ value parameter can be seen on Table 3.

Table 3. $\mathrm{IC}_{50}$ Value tyrosinase enzyme inhibitor corncob fraction

\begin{tabular}{lc}
\hline Fraction & $\mathrm{IC}_{50}$ value $(\mu \mathrm{g} / \mathrm{mL})$ \\
\hline Chloroform & 709.26 \\
Ethyl acetate & 185.76 \\
Aquadest & 676.44 \\
Kojic acid & 150.79 \\
\hline
\end{tabular}

Table 3 shows that the highest activity of inhibiting tyrosinase enzymes is corncob ethyl acetate fraction with the smallest $\mathrm{IC}_{50}$ value $185.76 \mu \mathrm{g} / \mathrm{mL}$, and its value is very close to positive control $\mathrm{IC}_{50}$ kojic acid $150.79 \mu \mathrm{g} /$ $\mathrm{mL}$. It is proven that corncob ethyl acetate fraction also can inhibit the tyrosinase enzyme.

\subsection{Correlation total phenolic and flavonoid content corncob fractions with antioxidant activity}

A parameter to describe total phenolic and flavonoids content towards free radicals capture is the determination coefficient $\left(\mathrm{R}^{2}\right)$ so that the correlation between antioxidant activity and entire phenolic and flavonoids content can be acknowledged (Rohman et al., 2017). Based on the correlation between entire phenolic content towards antioxidant activity shown Figure 2, the $\mathrm{R}^{2}$ value is 0.7646 ; this result indicates that the total phenolic content contributes $76.46 \%$ antioxidant activity. On the other hand, the correlation between entire flavonoid content towards antioxidant activity shown in

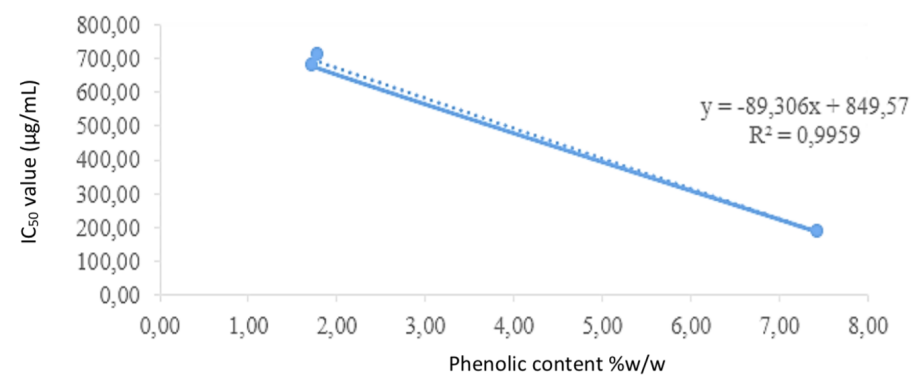

Figure 4. Correlation between total phenolic content valued $\mathrm{IC}_{50}$ corncob fraction with tyrosinase enzyme inhibitor
Figure 3 shows that the $\mathrm{R}^{2}$ values 0.7038 which means that the total flavonoid content can also contribute as much as $70.38 \%$ towards an antioxidant activity.

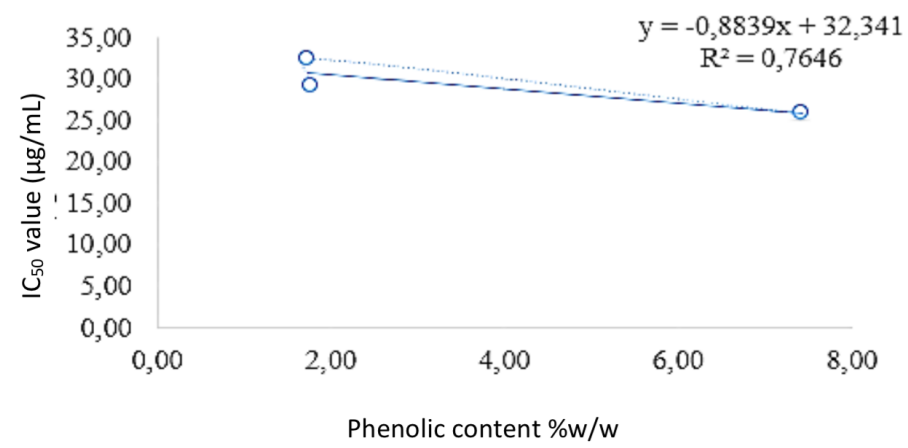

Figure 2. Correlation between total phenolic content valued $\mathrm{IC}_{50}$ corncob fractions with antioxidant activity

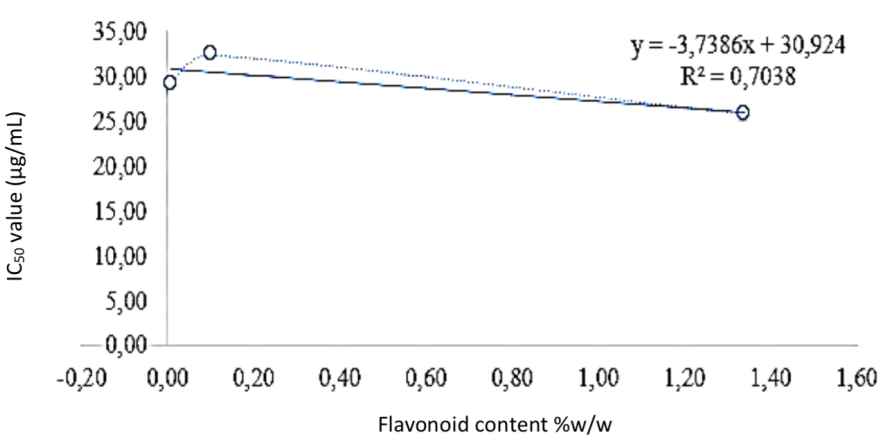

Figure 3. Correlation between total flavonoids content valued $\mathrm{IC}_{50}$ corncob fractions with antioxidant activity

Several researchers have reported previous research about the correlation between total phenolic and flavonoid content towards an antioxidant activity. Herlina et al. (2018) said that there was a correlation between entire phenolic content $\left(R^{2}=0.7309\right)$ and total flavonoid content $\left(R^{2}=0.3096\right)$ towards antioxidant activity in Kepel apple (Stelechocarpus burahol) extract and methanol fraction.

\subsection{Correlation total phenolic and flavonoid content corncob fractions with a tyrosinase enzyme inhibitor}

Figures 4 and 5 shows that the correlation of phenolic valued $\mathrm{R}^{2}$ is 0.9959 and total flavonoids valued $\mathrm{R}^{2}$ is 1 towards tyrosinase enzyme inhibition. This strong correlation is shown between tyrosinase enzyme

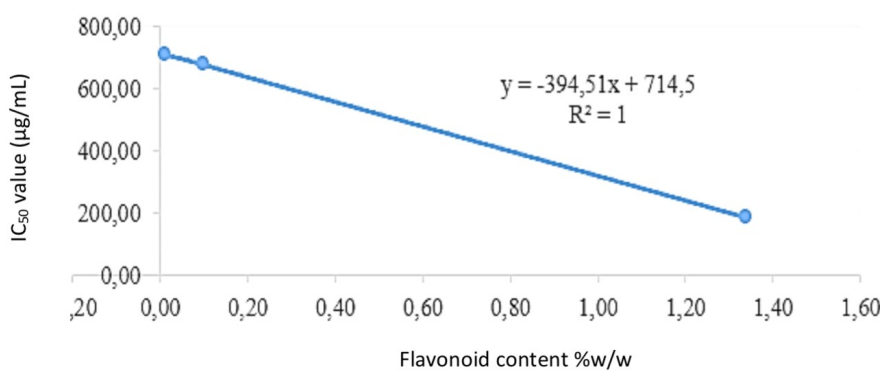

Figure 5. Correlation between total flavonoids content valued $\mathrm{IC}_{50}$ of corncob fractions with tyrosinase enzyme inhibitor 
inhibition on corncob fraction and total phenolic and flavonoids content. Thus, it can be concluded that phenolic and flavonoids contents have a significant contribution towards tyrosinase inhibition activity on corncob fraction. It is reported that the total phenolic and flavonoids content is correlated by contributing to inhibiting tyrosinase enzyme (Petrillo et al., 2016).

\section{Conclusion}

Based on the tyrosinase inhibitor test result, the highest tyrosinase activity is the ethyl acetate fraction with $\mathrm{IC}_{50}$ value of $185.76 \mu \mathrm{g} / \mathrm{mL}$ compared to the aqueous fraction ( $\left.\mathrm{IC}_{50} 676.44 \mu \mathrm{g} / \mathrm{mL}\right)$ and the chloroform fraction $\left(\mathrm{IC}_{50} 709.26 \mu \mathrm{g} / \mathrm{mL}\right.$ ). The result of antioxidant activity using the DPPH method shows that the highest antioxidant activity is the ethyl acetate fraction with $\mathrm{IC}_{50}$ value of $25.79 \mu \mathrm{g} / \mathrm{mL}$ compared to the chloroform fraction $\left(\mathrm{IC}_{50} 29.15 \mu \mathrm{g} / \mathrm{mL}\right)$ and the aqueous fraction $\left(\mathrm{IC}_{50} 32.41 \mu \mathrm{g} / \mathrm{mL}\right)$. The ethyl acetate corncob fraction contained a total phenolic content was $7.43 \% \mathrm{w} /$ w EAG, while the total flavonoid content was $1.34 \% \mathrm{w} /$ w EK. The ethyl acetate corncob fraction had tyrosinase and antioxidant activity, which correlates with total phenol and total flavonoid levels.

\section{Conflict of interest}

The authors declare no conflict of interest.

\section{Acknowledgments}

The author thanks Gadjah Mada of University, Indonesia, for its research funded by Thesis Recognition Program 2019 (Rekognisi Tugas Akhir 2019) to be done.

\section{References}

Alnajar, Z.A.A., Abdulla, M.A., Ali, H.M., Alshawsh, M.A. and Hadi, A.H.A. (2012). Acute toxicity evaluation, antibacterial, antioxidant and immunomodulatory effects of Melastoma malabathricum. Molecules, 17(3), 3547-3559. https://doi.org/10.3390/molecules17033547

Arung, E.T., Kusuma, I.W., Iskandar, Y.M., Yasutake, S., Shimizu, K. and Kondo, R. (2005). Screening of Indonesian Plants for Tyrosinase Inhibitory Activity. The Japan Wood Research Society, 51, 520- 525. https://doi.org/10.1007/s10086-004-0690-7

Asadollahi, M.; Bodi, Z., Peles, F. and Sandor, E. (2012). Antifungal activity of anthocyanins from purple field corncob against Botrytis cinerea and Fusarium species Antifungal activity of anthocyanins from purple field corncob against Botrytis cinerea and Fusarium species. Journal of Agricultural
Sciences, 50, 76-83.

Badan Pusat Statistik (2014) Data Produksi Jagung di Indonesia. Retrieved on January 10, 2020 from Badan Pusat Statistik website: http://www.bps.go.id

Batubara, I., Darusman, L.K., Mitsunaga, T., Rahminiwati, M. and Djauhari, E. (2010). Potency of Indonesian Medicinal Plants as Tyrosinase Inhibitor and Antioxidant Agent. Journal of Biological Sciences, 10(2), 138-144. https://doi.org/10.3923/ jbs.2010.138.144

Bin, B.-H., Cho, E.-G., Choi, E.-J., Kim, S., Choi, S. and Lee, T. (2018). Skin Whitening Composition and Method for Screening for Materials Having Skin Whitening Effect. Patent No: KR20170003000A. South Korea: Korea Intellectual Property Rights Information Service

Direktorat Jenderal Tanaman Pangan (2015) Laporan Kinerja Direktorat Jenderal Tanaman Pangan Tahun 2014. Jakarta : Kementerian Pertanian

Dong, J., Cai, L., Zhu, X., Huang, X., Yin, T., Fang, H. and Ding, Z. (2014). Antioxidant activities and phenolic compounds of cornhusk, corncob and stigma maydis. Journal of the Brazilian Chemical Society, 25(11), 1956-1964. https:// doi.org/10.5935/0103-5053.20140177

Gupta, D. (2015). Methods For Determination Of Antioxidant Capacity: A Review Deepshikha Gupta Department of Chemistry, Amity Institute of Applied Sciences, Amity University Uttar Pradesh, Sector 125, Noida-20130, India. International Journal of Pharmaceutical Sciences and Research, 6(2), 546566. doi: 10.13040/IJPSR.0975-8232.6(2).

Halliwell, B. (2006). Reactive Species and Antioxidants. Redox Biology Is. Plant Physology, 141(2), 312322. https://doi.org/10.1104/pp.106.077073

Hashemi, S.M. and Emami, S. (2015). Kojic acidderived tyrosinase inhibitors: synthesis and bioactivity. Pharmaceutical and Biomedical Research, 1(1), 1-17. https://doi.org/10.18869/ acadpub.pbr.1.1.1

Herlina, N., Riyanto, S., Martono, S. and Rohman, A. (2018). Antioxidant activities, phenolic and flavonoid contents of methanolic extract of Stelechocarpus burahol fruit and its fractions. Dhaka University Journal of Pharmaceutical Sciences, 17 (2), 153-159. https://doi.org/10.3329/ dujps.v17i2.39170

Jegal, J., Park, S.A., Chung, K.W., Chung, H.Y., Lee, J., Jeong, E.J. and Yang, M.H. (2016) Tyrosinase inhibitory flavonoid from Juniperus communis fruits. Bioscience, Biotechnology and Biochemistry, 80(12), 2311-2317. 
doi.org/10.1080/09168451.2016.1217146

Jin, Y., Kim, J.H., Hong, H., Kwon, J., Lee, E.J., Jang, M. and Huh, T. (2018). Ginsenosides Rg5 and Rk1, the skin-whitening agents in black ginseng. Journal of Functional Foods, 45, 67-74. https:// doi.org/10.1016/j.jff.2018.03.036

Kemenkes (2017). Farmakope Herbal Indonesia, 2nd ed. Jakarta : Kementerian Kesehatan RI

Kikuzaki, H., Hisamoto, M., Hirose, K., Akiyama, K. and Taniguchi, H. (2002). Antioxidant Properties of Ferulic Acid and Its Related Compounds. Journal Agricultural and Food Chemistry, 50, 2161-2168. https://doi.org/10.1021/jf011348w

Li, C.Y., Kim, H.W., Li, H., Lee, D.C. and Rhee, H.I. (2014). Antioxidative effect of purple corn extracts during storage of mayonnaise. Food Chemistry, 152, 592-596.

https://doi.org/10.1016/ j.foodchem.2013.11.152

Lumempouw, L.I., Suryanto, E. and Paendong, J.J.E. (2012). Aktivitas Anti UV-B Ekstrak Fenolik dari Tongkol Jagung (Zea mays L.). Jurnal MIPA UNSRAT Online, 1(1), 1-4. https://doi.org/10.35799/ jm.1.1.2012.422

Melo-Silveira, R.F., Viana, R.L.S., Sabry, D.A., da Silva, R.A., Machado, D., Nascimento, A.K.L., Scortecci, K.C., Ferreira-Halder, C.V., Sassaki, G.L. and Rocha, H.A.O. (2019). Antiproliferative xylan from corncobs induces apoptosis in tumor cells. Carbohydrate Polymers, 210, 245-253. https:// doi.org/10.1016/j.carbpol.2019.01.073

Molyneux, P. (2004). The Use of the Stable Free Radical Diphenylpicryl-hydrazyl (DPPH) for Estimating Antioxidant Activity. Songklanakarin Journal of Science and Technology, 26, 211-219. https:// doi.org/10.1287/isre.6.2.144

Petrillo, A.D., González-paramás, A.M., Era, B., Medda, R., Pintus, F., Santos-buelga, C. and Fais, A. (2016). Tyrosinase inhibition and antioxidant properties of Asphodelus microcarpus extracts. $B M C$ Complementary and Alternative Medicine, 16, 453. https://doi.org/10.1186/s12906-016-1442-0

Riswahyuli, Y., Rohman, A., Setyabudi, F.M.C.S. and Raharjo, S. (2019) Evaluation of Phenolic Content and Free Radical Scavenging Activity of Indonesia Wild Honey Collected from Seven Different Regions, Journal of Food Research, 8(6), 94-103. https://doi.org/10.5539/jfr.v8n6p94

Rohman, A., Riyanto, S., Mistriyani, Shuhaira and Nugroho, A.E. (2017) Antiradical Activities of Rambutan peel: Study from Two Cultivars. Research Journal of Phytochemistry, 11(1), 42-47. https:// doi.org/10.3923/rjphyto.2017.42.47
Sehwag, S. and Das, M. (2014). Antioxidant Activity: An Overview Antioxidant Activity. Research and Reviews: Journal of Food Science and Technology, 2 (3), $1-11$.

Suryanto, E. and Irma Momuat, L. (2017) Isolasi dan Aktivitas Antioksidan Fraksi dari Ekstrak Tongkol Jagung. Agritech, 37(2), $139 . \quad$ https:// doi.org/10.22146/agritech.27537 